\title{
NFkappaB is a Key Player in the Crosstalk between Inflammation and Cardiovascular Diseases
}

\author{
Antonella Fiordelisi ${ }^{1}$, Guido Iaccarino ${ }^{1}$ (D), Carmine Morisco ${ }^{1}$, Enrico Coscioni ${ }^{2}$ and \\ Daniela Sorriento ${ }^{1, *}$ \\ 1 Department of Advanced Biomedical Sciences, Federico II University of Naples, 80131 Napoli, Italy; \\ antonella.fiordelisi@gmail.com (A.F.); guiaccar@unina.it (G.I.); carmine.morisco@unina.it (C.M.) \\ 2 Division of Cardiac Surgery, AOU San Giovanni di Dio e Ruggi d'Aragona, 84131 Salerno, Italy; \\ coscionienrico@gmail.com \\ * Correspondence: daniela.sorriento@unina.it
}

Received: 19 February 2019; Accepted: 26 March 2019; Published: 30 March 2019

\begin{abstract}
Inflammation is a key mechanism of cardiovascular diseases. It is an essential component of atherosclerosis and a significant risk factor for the development of cardiovascular events. In the crosstalk between inflammation and cardiovascular diseases, the transcription factor NFKB seems to be a key player since it is involved in the development and progression of both inflammation and cardiac and vascular damage. In this review, we deal with the recent findings of the role of inflammation in cardiac diseases, focusing, in particular, on NFKB as a functional link. We describe strategies for the therapeutic targeting of $\mathrm{NF} \kappa \mathrm{B}$ as a potential strategy for the failing heart.
\end{abstract}

Keywords: inflammation; cardiovascular diseases; NFKB; GRK

\section{Inflammation in Cardiovascular Diseases}

Emerging evidence suggests that chronic inflammation participates in the development and progression of cardiovascular diseases (atherosclerosis, aortic valve disease, myocardial infarction, heart failure) and cardiometabolic disorders (obesity, insulin resistance) [1-8]. Equally important, several pro-inflammatory markers are elevated in patients with cardiomyopathies and have been correlated with the prognosis and severity of disease [2] suggesting a potential relationship between markers of inflammation and risk of future cardiovascular events [9].

\subsection{Inflammation and Atherosclerosis}

Atherosclerosis is a multi-step process that consists of four main phases: endothelium injury; foam cell formation; smooth muscle cell proliferation; formation and rupture of the atherosclerotic plaque. Both adaptive and innate immunity is involved in the development and progression of atherosclerosis [10]. Indeed, the adhesion molecules and chemokines in the early phases of the process promote the recruitment of both monocytes/macrophages and $\mathrm{T}$ cells. In particular, inflammatory cells are recruited from the circulation and migrate into activated endothelial cells. The endothelial migration is mainly mediated by cellular adhesion molecules such as vascular-cell adhesion molecule 1 (VCAM-1), which is typically up-regulated in response to hypercholesterolemia [11]. Through the chemo-attractant cytokine, MCP-1, leukocytes are recruited to the site of the lesion [12]. Once resident in the intima, the monocytes differentiate into macrophages that bind oxidized lipoproteins giving rise to the arterial foam cell (a hallmark of the arterial lesion). This latter secretes pro-inflammatory cytokines (IL-1 $\beta$, IL-6, IL-8, TNF $\alpha$, TGF $\beta$ ) that amplify the local inflammatory response, induces reactive oxygen species production and recruits VSMC to the site of the lesion. T cells in the lesion (Th1 subtype) induce the production of IFN $\gamma, \mathrm{IL}-2, \mathrm{TNF} \alpha$ which, in turn, cause the activation of 
macrophages and vascular cells and further promote inflammation [13]. Thus, inflammation clearly plays a key role in the atherosclerotic process since inflammatory cells are key effectors in its early phases, cytokines accelerate the progression of the lesions leading to plaque rupture, thrombosis and the clinical manifestation of the acute coronary syndrome [14].

Experimental studies in pre-clinical models suggest potential molecular mechanisms by which cytokines exert their effects. It is known that Ang II has pro-inflammatory effects in the vascular wall by inducing ROS production and NFKB activation which in turn induces the expression of cytokines, chemokines, and adhesion molecules, including IL-6, MCP-1 and VCAM-1 [15-17]. The interaction of the proinflammatory cytokine IL-6 with the renin-angiotensin system (RAS) has been suggested as an important pathogenetic mechanism in the atherosclerotic process [18]. Indeed, IL-6 induces oxidative stress and endothelial dysfunction in a model of atherosclerosis by activating the angiotensin II type 1 receptor and these effects are absent in transgenic mice with the deletion of AT1 receptor [18]. It has also been suggested that IL- 6 and MCP-1 secretion in response to ANG II are actually codependent and accelerates macrophage-mediated vascular inflammation [19].

The inflammatory process in atherosclerosis leads to increased blood levels of inflammatory cytokines and other molecules which are considered useful biomarkers of cardiac dysfunction. Indeed, the levels of C-reactive protein and interleukin- 6 are elevated in patients with unstable angina and myocardial infarction and it has been shown that high levels are associated with a worse prognosis [20,21].

\subsection{The Role of Inflammation in Myocardial Infarct and Heart Failure}

In response to the insults, several molecular mechanisms got activated in the heart to initiate the structural remodeling of the organ. This process involves both cardiac and non-cardiac cells, including inflammatory cells [22]. For instance, in response to acute myocardial infarction, there is an early increase of proinflammatory cytokines, such as TNF-alpha, IL-6, IL-1beta, and transforming growth factor 1-beta (TGF-1beta). The acute release of these inflammatory cytokines initially regulates the survival or apoptosis of myocytes in the infarcted zone [23]. However, in a later phase, the continuous increase of these cytokines production promotes interstitial fibrosis and collagen deposition in the non-infarcted zone leading to ventricle dysfunction [23,24]. Cytokines induce the activity of local matrix metalloproteinase (MMP2 and MMP9) in the infarcted area and the expression of natriuretic peptides (ANP and BNP) favoring cardiac remodeling [25]. These findings support the idea that inflammation exerts a cardioprotective role in the acute responses and a deleterious effect in the chronic responses (Figure 1).

At the molecular level, the upregulation of cytokines in the heart activates intracellular pathways which significantly affect cardiac cell biology: activation of transcription factors such as NFKB and AP-1 [26], cardiomyocytes survival and apoptosis [27], ROS production [28], and cardiac cell contractility [29]. The link between cytokines and oxidative stress is evident from the study of Machida and colleagues [28]. Indeed, in transgenic mice with overexpression of $\operatorname{TNF} \alpha$, the production of hydroxyl radical is increased and, accordingly, the antioxidant capacity of MnSOD is impaired [28]. Additionally, TNF $\alpha$ induces mitochondrial ROS production in cardiac myocytes [30] that is associated with mitochondrial DNA damage favoring the progression of heart failure [31].

Besides the effects on oxidative stress, cytokines such as TNF $\alpha$ and IL-6, are able to attenuate myocyte contractility in both direct and indirect manners. Indeed, TNF $\alpha$ directly reduces sarcoplasmic reticulum (SR) calcium uptake through the inhibition of SR calcium adenosine triphosphatase expression and activity [29] and this effect is rescued by the removal of cytokine exposure [32]. Furthermore, TNF $\alpha$ decreases myocyte contractility indirectly by inducing nitric oxide synthesis in isolated myocytes thus attenuating myofilament calcium responsiveness $[23,33]$.

Additionally, IL-1 $\beta$ has been shown to affect cardiac function by activating NO synthase activity in cardiac myocytes [34] which in turn lowers energy production and myocardial contractility via impairment of mitochondrial function [35]. Accordingly to these in vitro findings, targeting these pro-inflammatory cytokines could significantly affect the clinical outcomes of heart diseases, 
supporting the entangled role of inflammation in cardiovascular events through the regulation of mitochondrial function $[36,37]$.

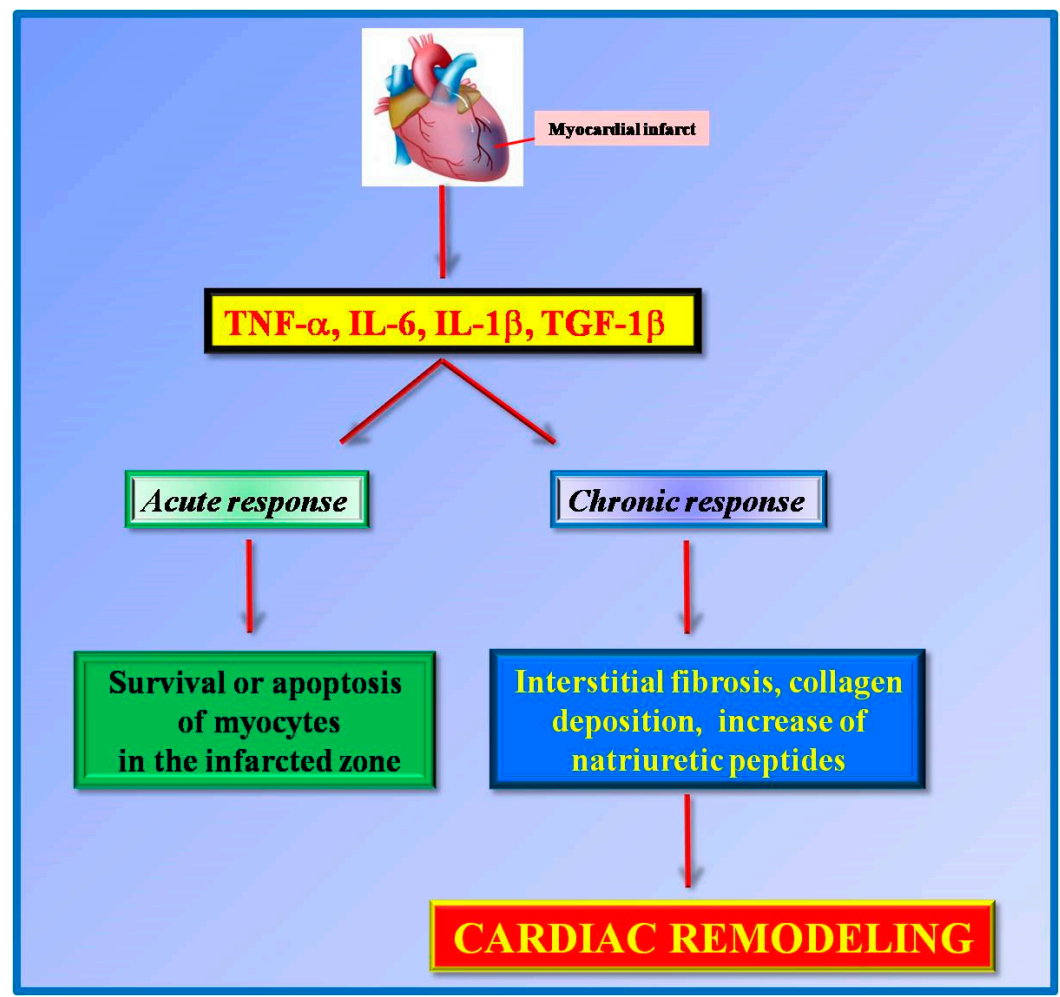

Figure 1. Pro-inflammatory cytokines (TNF $\alpha$, IL-6, IL1 $\beta$, TGF-1 $\beta$ ) are released in response to myocardial infarction. These cytokines exert different effects on acute and chronic responses. In an early phase, they exert a cardioprotective role by regulating the survival of cardiomyocytes in the infarcted area while in chronic responses these cytokines favor cardiac remodeling.

\subsection{Inflammation and Cardiovascular Risk}

An association between inflammation and cardiovascular risk has been suggested by the evidence that inflammatory cytokines, including IL-1 $\beta$, IL-6, IL-18, and TNF- $\alpha$, are increased in patients with heart failure, and increased inflammatory markers, such as C-reactive protein, predict a worse survival during acute coronary syndromes [36,38,39]. Increased levels of proinflammatory cytokines in response to myocardial damage are important prognostic factors, correlating with increased mortality rates in HF patients [40].

Moreover, the incidence of cardiovascular events is increased in patients affected by chronic inflammatory disease, such as Rheumatoid Arthritis (RA) and might sustain the increased risk of cardiovascular events in this population. Interestingly, though, in RA it is possible to observe structural abnormalities both at cardiac (increase ventricular mass, intraventricular septum end-diastolic thickness, LV posterior wall end-diastolic thickness, and aortic root diameter) and vascular (arterial stiffness, increased intima-media thickness of the carotid arteries) levels. These abnormalities may be due to the systemic effects of the immune system [41-43].

Accordingly, anti-inflammatory therapies reduce the risk of cardiovascular events in patients with rheumatoid arthritis, as demonstrated in large prospective cohort studies $[44,45]$ in RA patients treated with methotrexate. Furthermore, in RA patients the selective inhibition of TNF- $\alpha$ by means of infliximab and etanercept or the inhibition of IL-6 by tocilizumab exerted a positive effect on endothelial function [46]. Also, pre-clinical studies confirmed the atherogenic role of immune cells in rheumatoid arthritis that is associated with elevated levels of inflammatory cytokines [47,48]. 
TNF- $\alpha$, for instance, upregulates the expressions of adhesion molecules and chemokine, favoring the recruitment of monocytes to the lesions, and also increases SRA expression in macrophages favoring the uptake of oxidized LDL.

\section{Targeting Inflammatory Signaling in Cardiovascular Diseases}

The identification of specific cytokines which affect different intracellular signaling pathways in response to cardiac damage supported the idea that targeting these cytokines could ameliorate cardiac responses. Several pieces of evidence (study with monoclonal antibodies against the IL-1 $\beta$ and IL-6 receptor) support this hypothesis. Moreover, the evidence that the cardiovascular therapy (statins, phosphodiesterase inhibitors, antiarrhythmic, COX-2 inhibitors, Angiotensin II receptor blockers) also modulates cytokines expression and inflammatory signaling sustain the proof of concept that inflammation has a functional role in cardiovascular diseases.

\subsection{The Modulation of Inflammatory Proteins Expression}

Given the contribution of inflammation in the development of atherosclerotic plaque, different treatments have been tested which specifically act on inflammatory signaling [49]. These include the phospholipase A2 inhibitors, which act on atherogenic lipoproteins and foam cells [50], and some general antioxidants, that may affect inflammatory pathways at different steps of the atherosclerotic process [51]. Furthermore, statins, which are generally used to reduce cholesterol synthesis, have been shown to exert anti-inflammatory action independently from lipid-lowering effects [52,53]. Indeed, the treatment with statins reduces the expression of vascular cell adhesion molecule 1 and intracellular adhesion molecule 1 in human endothelial cells in vitro [54]. Accordingly, statins reduce the growth of macrophages and lowered the metalloproteinase activity to stabilize atherosclerotic plaques in vivo [55]. In animal models of atherosclerosis, statins reduce the inflammatory infiltrate in the arterial wall and the expression of different inflammatory cytokines [56]. Statins are also known to positively affect the outcomes in chronic heart failure [57] by improving cardiac function, and decreasing plasma concentrations of TNF- $\alpha$, IL-6, and brain (B-type) natriuretic polypeptide [58].

Additionally, phosphodiesterase inhibitors, which are used for the treatment of heart failure, are able to reduce the production of cytokines. In particular, pimobendan has been shown to decrease the production of intracardiac IL-1 $\beta$, IL- 6 , TNF- $\alpha$ and nitric oxide [59] by inhibiting the activation of NFKB [60] in mouse models of heart failure. Accordingly, in clinic pimobendan seems to improve the quality of life and to decrease the number of cardiovascular events in patients with heart failure [61]. In the same manner, amiodarone, an antiarrhythmic drug that improves the long-term prognosis of heart failure, has been shown to inhibit the production of TNF- $\alpha$ and IL-6 $[62,63]$. These findings suggest that the anti-inflammatory properties of this drug contribute to its beneficial cardiovascular effects.

Hypertension is among the main risk factor for developing cardiovascular diseases and, in particular, of atherosclerotic vascular diseases. Chronic inflammation causes the increase of oxidative stress, CRP synthesis, and pro-inflammatory cytokines production and this is associated with endothelial dysfunction in hypertension. It has been shown that anti-inflammatory treatments have also beneficial effects on vascular function. Indeed, COX-2 inhibition, by means of celecoxib, reduces CRP levels in patients with both severe CAD [64] and arterial hypertension [65] associating with an improved endothelial function. Additionally, the treatment with Angiotensin II receptor blockade reduces the levels of CRP, TNF $\alpha$, IL-6, and MCP-1 in patients with essential hypertension [66].

\subsection{The Therapeutic Monoclonal Antibodies}

Given the role of inflammation in several diseases, blocking the activity of the specific cytokine that is involved in the pathogenesis of the condition could provide an additional advantage over standard therapy. In this context, a novel technology, the therapeutic monoclonal antibodies (mAbs), has been proposed and it is now widely accepted to treat cancer, autoimmune and infectious diseases. Recently, 
this strategy has also been extended to the cardiovascular field and, in particular, the effectiveness of mAbs against specific inflammatory cytokines was tested in clinical trials. The CANTOS trial, for instance, involved over 10,000 patients with a previous myocardial infarction and high levels of C-reactive protein. Patients were treated with Canakinumab, a monoclonal antibody targeting IL-1 $\beta$, at different doses [67]. This study shows that Canakinumab at a dose of $150 \mathrm{mg}$ every 3 months lowers the rate of recurrent cardiovascular events compared to the placebo. Since it is known that Interleukin-1 $\beta$ strongly induces IL-6 production by many cell types including vascular endothelial and smooth muscle cells [68], it has also postulated that the ameliorated cardiovascular outcomes to canakinumab treatment could be mediated through the IL-6 signaling pathway. Indeed, canakinumab dependent reduction of IL-6 was associated with the reduction of cardiovascular events [69]. Additionally, in a randomized, controlled trial in regarding 100 patients with N-STEMI, a single dose of Tocilizumab, a humanized anti-IL-6 receptor antibody, prior to coronary angiography, attenuated the inflammatory response [70]. In parallel to the CANTOS study, the CIRT study was performed to evaluate the effectiveness of an alternative approach to inflammation inhibition (methotrexate) in patients with previous myocardial infarction or multivessel coronary disease who also had either type 2 diabetes or metabolic syndrome [71]. Patients were treated with Methotrexate, an inhibitor of folic acid, given the effectiveness of this anti-inflammatory drug in patients with RA. However, low doses of methotrexate failed to prevent cardiovascular events and to reduce IL-1b, IL-6 and CRP levels [71], being in contrast with CANTOS study. However, it should be taken into account that inclusion criteria for patients enrollment were different since CIRT did not screen for CRP levels while CANTOS enrolled patients with high levels of CRP. Moreover, the therapeutic targets are also different underlining the importance of specific inflammatory signaling in the development of cardiac events and the effectiveness of therapeutic monoclonal antibodies compared with generic anti-inflammatory drugs.

The complexity of the role of inflammation in cardiovascular diseases is testified by the failure of a number of trials showing that monoclonal antibodies raised against specific cytokines worsened prognosis. Indeed, data from a clinical trial show that in patients with heart failure the treatment with Infliximab, a chimeric monoclonal antibody to TNF- $\alpha$, or Etanercept, a soluble TNF receptor, increased mortality [72]. Thus, the beneficial effects of therapeutic treatments for heart failure could be just in part due to the modulation of inflammatory responses but the best treatment is the one which affects both inflammation and cardiac damage mechanisms.

\section{Molecular Mechanisms Involved in Inflammatory Responses: the Role of $\mathrm{NF}_{\kappa} \mathrm{B}$}

Different molecular mechanisms activate inflammatory responses leading to cytokine production and release. The type of cytokine and its specific effect differ during an inflammatory response depending on tissues and specific physio-pathological condition. However, a common feature of inflammatory intracellular signaling is the activation of specific transcription factors which drive the expression of cytokine production. Among them, NFkB is the best-known director of this phenomenon. $\mathrm{NF} \kappa \mathrm{B}$ is a ubiquitous transcription factor involved in cellular responses to stimuli such as stress, cytokines, free radicals, ultraviolet irradiation, oxidized LDL, and bacterial or viral antigens [73-77].

The family of NFKB proteins includes p52/p100, p50/p105, c-Rel, RelA/p65, and RelB. These proteins function as dimeric transcription factors that regulate the expression of genes thus affecting a broad range of biological processes. In the canonical pathway, NFKB is bound and inhibited by IKB proteins. Proinflammatory cytokines, LPS, growth factors, and antigen receptors activate an IKK complex (IKK $\beta$, IKK $\alpha$, and NEMO), which phosphorylates IKB proteins inducing their ubiquitination and proteasomal degradation. $\mathrm{NFKB}$ is, therefore, free to translocate to the nucleus where alone or in combination with other transcription factors (AP-1, Ets, and Stat) induces target gene expression [78]. In the non-canonical pathway, p100/RelB complexes are inactive in the cytoplasm. After receptor activation, including LT $\beta$ R, CD40, and BR3, the kinase NIK is activated inducing IKK $\alpha$ complexes. 
These latter phosphorylate p100 that is proteolytically processed to p52 which, together with RelB complexes, translocate to the nucleus and induce target gene expression [78].

The activation of $N F \kappa B$ depends on different stimuli. In the heart, both innate and adaptive immunity are involved in responses to tissue injury due to pathogen-associated molecular patterns (PAMPs) or damage associated molecular patterns (DAMPs) which stimulate specific membrane receptors pattern recognition receptors (PRRs) [79]. Many PRRs triggered by PAMPs and DAMPs initiate a signaling cascade which culminates into the activation of $N F \kappa B$, beyond the activator protein 1 , the interferon regulatory factors transcription factor and the inflammasome [79].

The pathogenetic role of NFKB has been demonstrated in many diseases from cancer to cardiovascular diseases [80-82], where it exerts a double effect: regulation of immunity by driving the expression of genes involved in inflammation [83] and regulation of the expression of specific target genes involved in the progression of the pathology. This suggests that NFKB could be a potent therapeutic target in those pathologies which are characterized by the elevated activity of this transcription factor and for which inflammation favors organ damage, such as in cardiovascular diseases.

\section{NFKB in Cardiovascular Diseases}

Several reports show that the transcription factor NFKB, known to regulate the expression of inflammatory cytokines, also activates genes involved in various cardiovascular diseases, in the pathogenesis of cardiac remodeling and heart failure [84-86]. NFKB is activated in the heart in many conditions: during acute ischemia and reperfusion [87-89], during unstable angina $[86,90]$ or in response to preconditioning [91]. In patients with heart failure, for instance, NFKB is activated both in cardiomyocytes [92] and in peripheral white blood cells [93]. However, its role in these pathological conditions still remains unknown. Several studies suggest that NFkB is cardioprotective during acute hypoxia and reperfusion injury through the inhibition of BNIP-3 expression [94]. However, in cardiac remodeling, the prolonged activation of $N F K B$ is cytotoxic and promotes heart failure by triggering a chronic inflammatory response [95]. These controversial results confirm that NFkB signaling is a very complex process involving several components and at multiple steps of regulation. In this complexity, timing and cellular context are critical factors for the NFKB effect.

The proof of concept that this transcription factor is involved in the development and progression of heart diseases comes from pre-clinical studies. In a mouse model with a cardiomyocyte-specific expression of a constitutively active form of IKK2, hearts showed inflammatory infiltrate, fibrosis and atrophy of myocytes [96]. The expression of $I \kappa B \alpha$ super-repressor, which inhibits NFkB, prevented the development of the disease suggesting that this phenomenon is dependent on NFkB activation [96]. Accordingly, 4 weeks after coronary ligation, transgenic mice with the cardiac-selective overexpression of the I $\mathrm{k} \mathrm{B} \alpha$ super-repressor showed improved survival, chamber remodeling, systolic function, and pulmonary congestion, associated with a reduction of NFKB p65 activation, cytokine expression, fibrosis, and apoptosis [97]. NFkB is also a fine regulator of cardiac hypertrophy. Indeed, cardiac-specific deletion of p65 in mice decreases the hypertrophic response in response to pressure overload stimulation, leading to a reduction of pathological remodeling and the rescue of contractile function [98]. In this model of cardiovascular disease, the interaction between NFKB and the nuclear factors of activated T cells (NFAT) has been hypothesized. Additionally, the inhibition of NFkB using direct gene delivery of sh-p65-RNA results in regression of cardiac hypertrophy [99].

\section{Targeting NF $\kappa B$ in the Failing Heart: the Role of GRKs}

As described above, the anti-inflammatory treatment alone resulted not enough to revert cardiac damage [72] but drugs for the treatment of cardiovascular diseases that also have anti-inflammatory properties were more efficient acting on both inflammation and cardiac damage [100-103]. Thus, for the development of a novel effective therapeutic strategy, it is essential to find a potential target that is involved in both processes. In this context, NFKB seems to be a good candidate since it regulates both cytokine production and hypertrophic genes expression. 
In the last decades, several inhibitors of NFKB have been developed, which act at different steps of its intracellular signaling pathway [104,105] (Figure 2), including anti-oxidants [106,107], proteasome and proteases inhibitors [108,109], inhibitors of IкB $\alpha[110,111]$, and miscellaneous inhibitors [112,113]. These compounds, although inhibiting NFkB, showed also toxic effects. The proteasome inhibition, for example, blocks the degradation of all ubiquitinated proteins within the cell greatly affecting cell biology and causing severe side effects. Therefore, most of them failed transferability to the clinical scenario. Therefore, there is a need for the identification of novel therapeutic relevant targets of NFKB signaling.

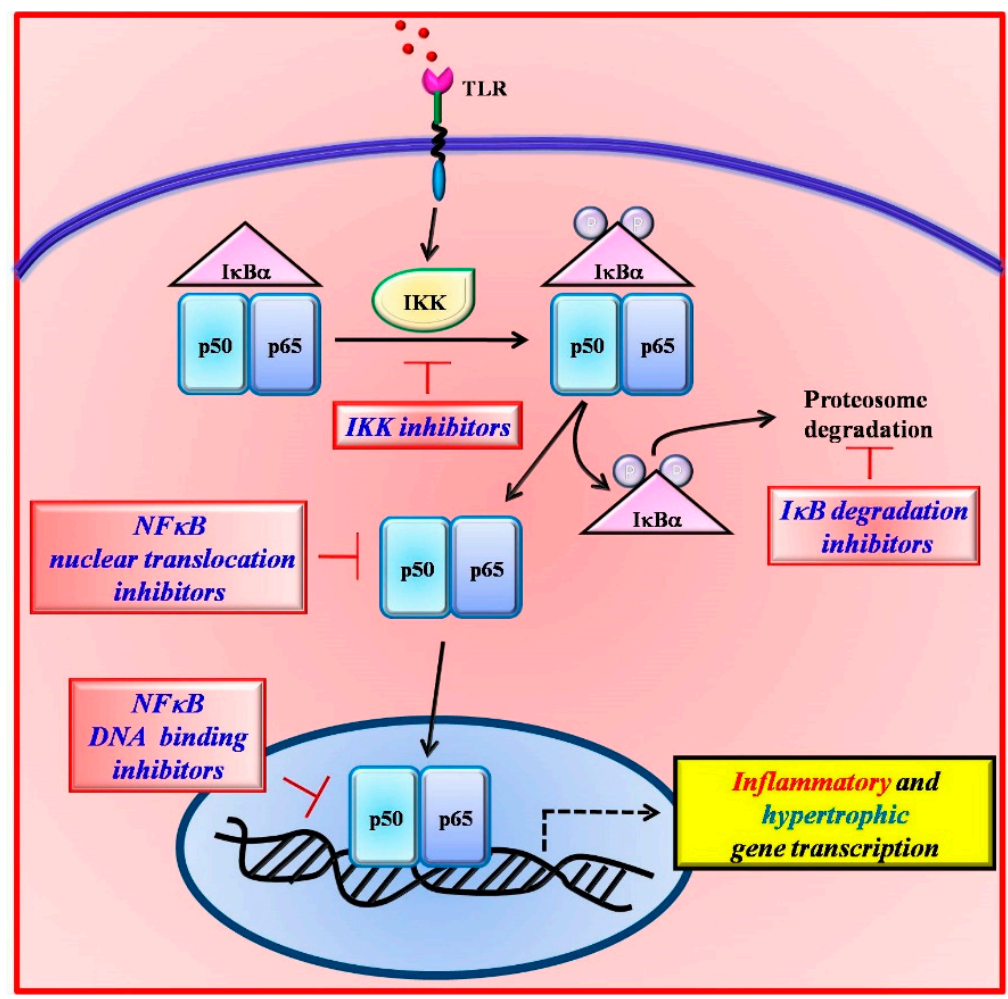

Figure 2. The inhibition of NFkB signaling can occur at different steps of its activation pathway. Several inhibitors have been designed which act on IKB $\alpha$ degradation (TP-110), IKK activity (EF-24), NFKB nuclear translocation (SN-50), and DNA binding (tacrolimus).

Besides their well-known effects in failing cardiac cells [114-118], the involvement of G Protein-Coupled Receptor Kinases (GRK) in inflammatory processes has been recently described [119-121]. Several observations suggest that GRKs play a critical role in different inflammatory disorders and in autoimmune diseases such as multiple sclerosis and rheumatoid arthritis. Indeed, in peripheral blood, mononuclear cells collected from patients with autoimmune diseases, GRK2 and GRK6 are significantly reduced [122,123] and this is associated with an increased GPCRs downstream signaling (enhanced cAMP and reduced TNF- $\alpha$ production) [124]. Actually, three members of the GRKs family (GRK2, GRK5, and GRK6) have been shown to affect inflammatory responses through the specific regulation of NFKB signaling [125-127].

GRK2 affects NFKB signaling by interacting with $\mathrm{I} \kappa \mathrm{B} \alpha$ and p105 [127]. GRK2 phosphorylates $\mathrm{I} \kappa \mathrm{B} \alpha$ in response to TNF $\alpha$ in a macrophage cell line and in HEK293 cells [128]. Furthermore, GRK2 interacts with p105 thus inhibiting the ERK pathway in primary macrophages [129]. In neonatal rat cardiac fibroblasts, NFKB activation and IL6 levels were increased in response to arginine vasopressin, thus linking GRK2 to inflammation in response to cardiac stress [130]. Conversely, NFkB regulates GRK2 expression during inflammation [121]. 
GRK5 regulates NFKB signaling both in a kinase-dependent and independent manner. Indeed, it can directly phosphorylate NFKB p105, thus inhibiting LPS-dependent ERK activation in macrophages [126]. Furthermore, GRK5 interacts with I $\kappa \mathrm{B} \alpha$ through means of the RH domain and inhibits its degradation leading to the inhibition of NFKB activity in endothelial cells [131].

In response to TNF- $\alpha$, GRK6 directly phosphorylates I $\mathrm{B} \alpha$ and induces its degradation by the proteasome. This promotes NFKB transcriptional activity and increases inflammatory responses [132].

Given the involvement of GRKs in both inflammatory and cardiac diseases and their ability to regulate $\mathrm{NFKB}$, several inhibitors have been designed on the GRKs sequence [115]. Among them, two specific compounds resulted to be effective inhibitors of NFkB in the heart: a peptide which reproduces the RH domain of GRK5 (TAT-RH) and the inhibitor of GRK2 kinase activity (Ant-124) (Figure 3).

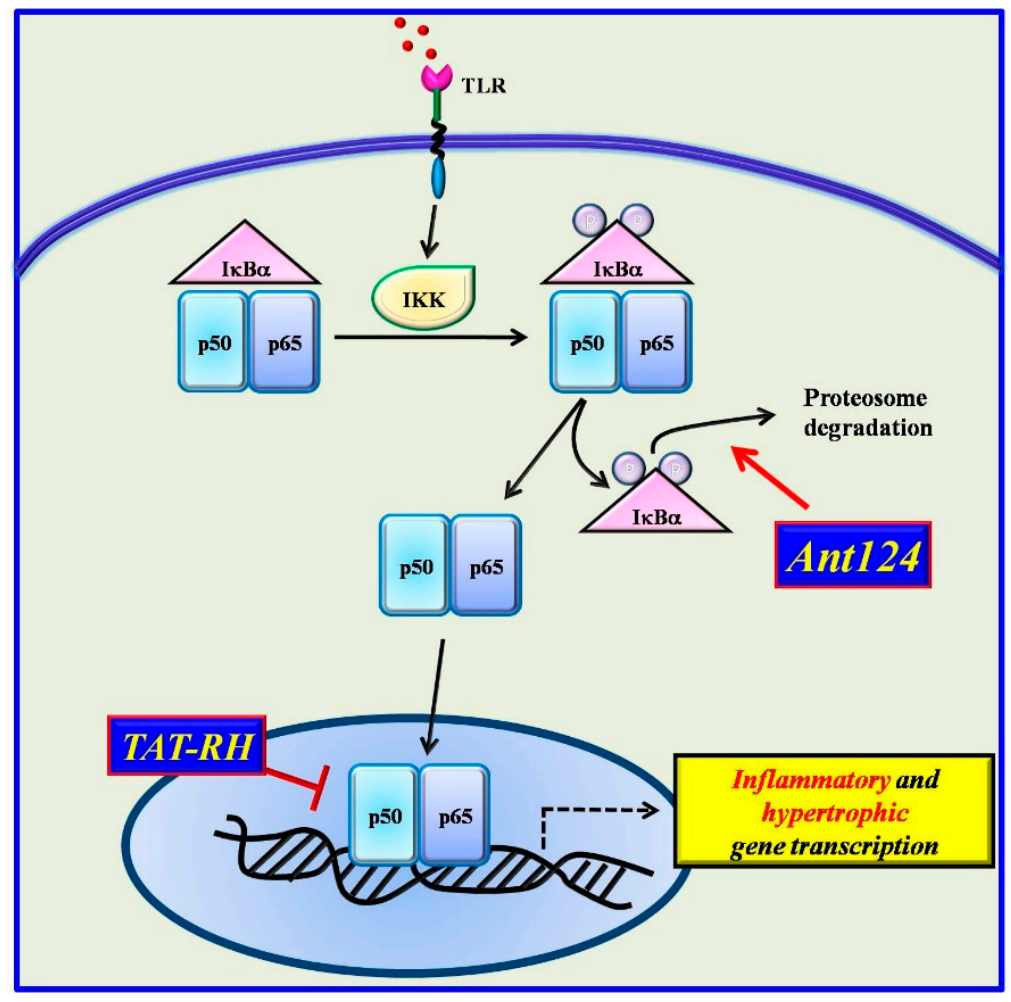

Figure 3. Two novel inhibitors have been designed based on the structure of GRKs. Ant124, which reproduces the HJ loop of GRK2, inhibits NFkB activation by blocking I $\mathrm{B} \alpha$ degradation. TAT-RH, which reproduces the RH domain of GRK5, binds $I \kappa B \alpha$ and blocks the complex I $\kappa$ B $\alpha / N F \kappa B$ in the nucleus thus preventing NFKB activation.

\subsection{The RH Domain of GRK5}

It has been recently demonstrated that GRK5 regulates the transcriptional activity of NFKB [131]. In particular, in endothelial cells, GRK5 is able to bind the inhibitory protein of NFkB, I $\kappa B \alpha$, by means of the RH domain (GRK5-RH) and to stabilize the complex IкB $\alpha / N F \kappa B$ in the nucleus, thus inhibiting $\mathrm{NF} \kappa \mathrm{B}$ transcriptional activity [131]. Indeed, GRK5-RH overexpression, by interacting with I $\kappa \mathrm{B} \alpha / \mathrm{NF} \kappa \mathrm{B}$ complex, inhibits the transcriptional activity and DNA binding of NFKB both in the basal condition and after stimulation with LPS. GRK5-RH was shown to inhibit all NFKB dependent phenotypes, such as TNF-alpha transcription, endothelial cell migration and vascular tube formation in vitro and regenerative responses in vivo. Given these features of GRK5-RH, its effects were evaluated in different pathologies characterized by the elevated activity of NFKB: cardiac hypertrophy [133] and cancer [134]. In particular, in cardiomyoblasts, GRK5-NT inhibits phenylephrine-induced transcription of both NFKB and atrial natriuretic factor promoters. In vivo, its effect was evaluated in two different animal models 
of left ventricular hypertrophy: the spontaneously hypertensive rat and the normotensive Wistar Kyoto rat exposed to the chronic administration of phenylephrine. Intracardiac injection of an adenovirus encoding for GRK5-NT reduced cardiac mass in spontaneously hypertensive rats and prevented the development of phenylephrine-induced LVH in Wistar Kyoto rats. This was associated with the inhibition of NFKB transcriptional activity and its associated phenotypes (fibrosis and apoptosis) [133].

Given the notion that the adenoviral-mediated gene therapy seems to be not efficient for clinical application due to the toxicity and immunogenicity induced by the adenovirus itself, a synthetic protein reproducing the only RH domain of GRK5 (TAT-RH), engineered to be actively transported into the cells by means of the TAT domain without the support of other vehicles, has been developed. TAT-RH was tested in cancer cells showing its ability to inhibit NFKB transcription and induce apoptosis, reduce tumor angiogenesis, block cell proliferation and consequently tumor growth in a dose-dependent manner [134]. Successively, a minimum effective sequence of TAT-RH was designed reproducing only 10 amino acids of the RH sequence (RH10) that is effective to inhibit cancer growth and reduce oxidative stress [135]. RH10 has not been tested in the cardiovascular field yet, but these findings are promising of the RH10 effectiveness in cardiovascular diseases too. Compared with the other NFKB inhibitors, this strategy is based on a steric interaction of RH10 and $\mathrm{I} K \mathrm{~B} \alpha$ and therefore does not require the inhibition of a general cellular mechanism such as the proteasome, suggesting that the side effects of chronic treatment with RH10, or a small molecule resembling it, will be of minimal intensity.

\subsection{Synthetic Inhibitors of GRK2}

Similarly to GRK5, GRK2 is able to phosphorylate $\mathrm{I} \kappa \mathrm{B} \alpha$, even if with a lower affinity [136]. Such ability allows the kinase to regulate NFKB signaling in pathological conditions. Indeed, in cardiomyoblasts, the overexpression of GRK2 increased phenylephrine-dependent hypertrophic gene expression, and this was associated with an increase of the NFKB transcriptional activity [84]. The kinase-dead mutant of the kinases exerted the opposite effect, suggesting that GRK2 could regulate hypertrophy through the upregulation of NFKB activity in a phosphorylation-dependent manner. Thus, the inhibition of GRK2 activity could ameliorate cardiac function in response to hypertrophic stimuli. A synthetic peptide inhibitor of GRK2 was designed based on the catalytic domain sequence of GRK2 and conjugated with the antennapedia internalization sequence (Ant124). This peptide effectively inhibits the GRK2 catalytic activity and the phenotypes associated with GRK2 activation [137]. In two different in vivo models of left ventricle hypertrophy (LVH), the selective inhibition of GRK2 activity by Ant124 prevented hypertrophy and reduced the NFKB transcription activity [84]. Such results strongly support the idea that the inhibition of GRK2 could be an effective therapeutic strategy to both ameliorate cardiac function and reduce inflammatory responses which are associated with the excessive activity of NFKB.

\section{Conclusions}

Inflammation plays a key role in the development and progression of cardiovascular diseases as demonstrated by its involvement in atherosclerotic processes and its association with increased risk for cardiovascular events. Furthermore, several clinical trials demonstrate the effectiveness of anti-inflammatory treatment in the management of cardiovascular diseases. In this context, the transcription factor NFKB could represent a functional bridge between inflammation and cardiac pathologies. Indeed, the release of cytokines from activated macrophages which infiltrate the cardiac tissue induces the activation of NFKB also in the cardiomyocyte leading to hypertrophic gene expression and cardiac damage. The effectiveness of GRK-dependent inhibition of NFKB suggests that it could represent a potential therapeutic target for the treatment of cardiac dysfunction and the associated inflammatory phenotype. However, it should be considered that the systemic delivery of NFKB inhibitors could induce side effects by affecting other non-target organs. Thus, in the future, strategies for tissue-specific targeting of such inhibitors (i.e., the use of nanotechnology) should be developed to avoid potential side effects. 
Author Contributions: A.F., G.I. and D.S. performed literature research and wrote the paper. C.M. and E.C. performed critical reading.

Funding: This research received no external funding.

Conflicts of Interest: The authors declare no conflict of interest.

\section{References}

1. Briasoulis, A.; Androulakis, E.; Christophides, T.; Tousoulis, D. The role of inflammation and cell death in the pathogenesis, progression and treatment of heart failure. Heart Fail. Rev. 2016, 21, 169-176. [CrossRef] [PubMed]

2. Dick, S.A.; Epelman, S. Chronic heart failure and inflammation: What do we really know? Circ. Res. 2016, 119, 159-176. [CrossRef]

3. Mehta, J.L.; Pothineni, N.V. Inflammation in heart failure: The holy grail? Hypertension 2016, 68, $27-29$. [CrossRef]

4. Libby, P. Inflammation in atherosclerosis. Nature 2002, 420, 868-874. [CrossRef]

5. Danesh, J.; Collins, R.; Appleby, P.; Peto, R. Association of fibrinogen, C-reactive protein, albumin, or leukocyte count with coronary heart disease: Meta-analyses of prospective studies. JAMA 1998, 279, 1477-1482. [CrossRef]

6. Pepys, M.B.; Hirschfield, G.M. C-reactive protein: A critical update. J. Clin. Investig. 2003, 111, $1805-1812$. [CrossRef] [PubMed]

7. Charles-Schoeman, C. Cardiovascular disease and rheumatoid arthritis: An update. Curr. Rheumatol. Rep. 2012, 14, 455-462. [CrossRef] [PubMed]

8. Aikawa, M.; Manabe, I.; Chester, A.; Aikawa, E. Cardiovascular inflammation. Int. J. Inflam. 2012, 2012, 904608. [CrossRef] [PubMed]

9. Willerson, J.T.; Ridker, P.M. Inflammation as a cardiovascular risk factor. Circulation 2004, 109, II2-II10. [CrossRef] [PubMed]

10. Packard, R.R.; Lichtman, A.H.; Libby, P. Innate and adaptive immunity in atherosclerosis. Semin. Immunopathol. 2009, 31, 5-22. [CrossRef] [PubMed]

11. Mach, F. The role of chemokines in atherosclerosis. Curr. Atheroscler. Rep. 2001, 3, 243-251. [CrossRef] [PubMed]

12. Munro, J.M. Endothelial-leukocyte adhesive interactions in inflammatory diseases. Eur. Heart J. 1993, 14, 72-77.

13. Hansson, G.K.; Libby, P.; Schonbeck, U.; Yan, Z.Q. Innate and adaptive immunity in the pathogenesis of atherosclerosis. Circ. Res. 2002, 91, 281-291. [CrossRef]

14. Hansson, G.K. Inflammation, atherosclerosis, and coronary artery disease. N. Engl. J. Med. 2005, 352, 1685-1695. [CrossRef]

15. Brasier, A.R.; Recinos, A., 3rd; Eledrisi, M.S. Vascular inflammation and the renin-angiotensin system. Arterioscler. Thromb. Vasc. Biol. 2002, 22, 1257-1266. [CrossRef] [PubMed]

16. Pueyo, M.E.; Gonzalez, W.; Nicoletti, A.; Savoie, F.; Arnal, J.F.; Michel, J.B. Angiotensin II stimulates endothelial vascular cell adhesion molecule-1 via nuclear factor-kappaB activation induced by intracellular oxidative stress. Arterioscler. Thromb. Vasc. Biol. 2000, 20, 645-651. [CrossRef]

17. Deng, B.; Fang, F.; Yang, T.; Yu, Z.; Zhang, B.; Xie, X. Ghrelin inhibits AngII -induced expression of TNF-alpha, IL-8, MCP-1 in human umbilical vein endothelial cells. Int. J. Clin. Exp. Med. 2015, 8, 579-588.

18. Wassmann, S.; Stumpf, M.; Strehlow, K.; Schmid, A.; Schieffer, B.; Bohm, M.; Nickenig, G. Interleukin-6 induces oxidative stress and endothelial dysfunction by overexpression of the angiotensin II type 1 receptor. Circ. Res. 2004, 94, 534-541. [CrossRef]

19. Tieu, B.C.; Lee, C.; Sun, H.; Lejeune, W.; Recinos, A., 3rd; Ju, X.; Spratt, H.; Guo, D.C.; Milewicz, D.; Tilton, R.G.; et al. An adventitial IL-6/MCP1 amplification loop accelerates macrophage-mediated vascular inflammation leading to aortic dissection in mice. J. Clin. Investig. 2009, 119, 3637-3651. [CrossRef] [PubMed]

20. Liuzzo, G.; Biasucci, L.M.; Gallimore, J.R.; Grillo, R.L.; Rebuzzi, A.G.; Pepys, M.B.; Maseri, A. The prognostic value of C-reactive protein and serum amyloid a protein in severe unstable angina. N. Engl. J. Med. 1994, 331, 417-424. [CrossRef] [PubMed] 
21. Biasucci, L.M.; Vitelli, A.; Liuzzo, G.; Altamura, S.; Caligiuri, G.; Monaco, C.; Rebuzzi, A.G.; Ciliberto, G.; Maseri, A. Elevated levels of interleukin-6 in unstable angina. Circulation 1996, 94, 874-877. [CrossRef] [PubMed]

22. Frieler, R.A.; Mortensen, R.M. Immune cell and other noncardiomyocyte regulation of cardiac hypertrophy and remodeling. Circulation 2015, 131, 1019-1030. [CrossRef]

23. Nian, M.; Lee, P.; Khaper, N.; Liu, P. Inflammatory cytokines and postmyocardial infarction remodeling. Circ. Res. 2004, 94, 1543-1553. [CrossRef]

24. Mann, D.L. Stress-activated cytokines and the heart: From adaptation to maladaptation. Annu. Rev. Physiol. 2003, 65, 81-101. [CrossRef] [PubMed]

25. Deten, A.; Volz, H.C.; Briest, W.; Zimmer, H.G. Cardiac cytokine expression is upregulated in the acute phase after myocardial infarction. Experimental studies in rats. Cardiovasc. Res. 2002, 55, 329-340. [CrossRef]

26. Ha, T.; Liu, L.; Kelley, J.; Kao, R.; Williams, D.; Li, C. Toll-like receptors: New players in myocardial ischemia/reperfusion injury. Antioxid. Redox Signal. 2011, 15, 1875-1893. [CrossRef] [PubMed]

27. MacEwan, D.J. TNF receptor subtype signalling: Differences and cellular consequences. Cell Signal. 2002, 14, 477-492. [CrossRef]

28. Machida, Y.; Kubota, T.; Kawamura, N.; Funakoshi, H.; Ide, T.; Utsumi, H.; Li, Y.Y.; Feldman, A.M.; Tsutsui, H.; Shimokawa, H.; et al. Overexpression of tumor necrosis factor-alpha increases production of hydroxyl radical in murine myocardium. Am. J. Physiol. Heart Circ. Physiol. 2003, 284, H449-H455. [CrossRef] [PubMed]

29. Tsai, C.T.; Wu, C.K.; Lee, J.K.; Chang, S.N.; Kuo, Y.M.; Wang, Y.C.; Lai, L.P.; Chiang, F.T.; Hwang, J.J.; Lin, J.L. TNF-alpha down-regulates sarcoplasmic reticulum $\mathrm{Ca}(2)(+)$ ATPase expression and leads to left ventricular diastolic dysfunction through binding of NF-kappaB to promoter response element. Cardiovasc. Res. 2015, 105, 318-329. [CrossRef] [PubMed]

30. Nakamura, K.; Fushimi, K.; Kouchi, H.; Mihara, K.; Miyazaki, M.; Ohe, T.; Namba, M. Inhibitory effects of antioxidants on neonatal rat cardiac myocyte hypertrophy induced by tumor necrosis factor-alpha and angiotensin II. Circulation 1998, 98, 794-799. [CrossRef]

31. Suematsu, N.; Tsutsui, H.; Wen, J.; Kang, D.; Ikeuchi, M.; Ide, T.; Hayashidani, S.; Shiomi, T.; Kubota, T.; Hamasaki, N.; et al. Oxidative stress mediates tumor necrosis factor-alpha-induced mitochondrial DNA damage and dysfunction in cardiac myocytes. Circulation 2003, 107, 1418-1423. [CrossRef]

32. Yokoyama, T.; Vaca, L.; Rossen, R.D.; Durante, W.; Hazarika, P.; Mann, D.L. Cellular basis for the negative inotropic effects of tumor necrosis factor-alpha in the adult mammalian heart. J. Clin. Investig. 1993, 92, 2303-2312. [CrossRef] [PubMed]

33. Goldhaber, J.I.; Kim, K.H.; Natterson, P.D.; Lawrence, T.; Yang, P.; Weiss, J.N. Effects of TNF-alpha on [Ca2+]i and contractility in isolated adult rabbit ventricular myocytes. Am. J. Physiol. 1996, 271, H1449-H1455. [CrossRef] [PubMed]

34. Schulz, R.; Panas, D.L.; Catena, R.; Moncada, S.; Olley, P.M.; Lopaschuk, G.D. The role of nitric oxide in cardiac depression induced by interleukin-1 beta and tumour necrosis factor-alpha. Br. J. Pharmacol. 1995, 114, 27-34. [CrossRef]

35. Tatsumi, T.; Matoba, S.; Kawahara, A.; Keira, N.; Shiraishi, J.; Akashi, K.; Kobara, M.; Tanaka, T.; Katamura, M.; Nakagawa, C.; et al. Cytokine-induced nitric oxide production inhibits mitochondrial energy production and impairs contractile function in rat cardiac myocytes. J. Am. Coll. Cardiol. 2000, 35, 1338-1346. [CrossRef]

36. Van Tassell, B.W.; Raleigh, J.M.; Abbate, A. Targeting interleukin-1 in heart failure and inflammatory heart disease. Curr. Heart Fail. Rep. 2015, 12, 33-41. [CrossRef]

37. Gambardella, J.; Santulli, G. Integrating diet and inflammation to calculate cardiovascular risk. Atherosclerosis 2016, 253, 258-261. [CrossRef] [PubMed]

38. Gullestad, L.; Aukrust, P. Review of trials in chronic heart failure showing broad-spectrum anti-inflammatory approaches. Am. J. Cardiol. 2005, 95, 17-23. [CrossRef]

39. Aukrust, P.; Yndestad, A.; Damas, J.K.; Gullestad, L. Inflammation and chronic heart failure-potential therapeutic role of intravenous immunoglobulin. Autoimmun. Rev. 2004, 3, 221-227. [CrossRef]

40. Mann, D.L. Inflammatory mediators and the failing heart: Past, present, and the foreseeable future. Circ. Res. 2002, 91, 988-998. [CrossRef]

41. Yndestad, A.; Damas, J.K.; Oie, E.; Ueland, T.; Gullestad, L.; Aukrust, P. Role of inflammation in the progression of heart failure. Curr. Cardiol. Rep. 2007, 9, 236-241. [CrossRef] 
42. Dhawan, S.S.; Quyyumi, A.A. Rheumatoid arthritis and cardiovascular disease. Curr. Atheroscler. Rep. 2008, 10, 128-133. [CrossRef]

43. Avina-Zubieta, J.A.; Thomas, J.; Sadatsafavi, M.; Lehman, A.J.; Lacaille, D. Risk of incident cardiovascular events in patients with rheumatoid arthritis: A meta-analysis of observational studies. Ann. Rheum. Dis. 2012, 71, 1524-1529. [CrossRef]

44. Choi, H.K.; Hernan, M.A.; Seeger, J.D.; Robins, J.M.; Wolfe, F. Methotrexate and mortality in patients with rheumatoid arthritis: A prospective study. Lancet 2002, 359, 1173-1177. [CrossRef]

45. Krishnan, E.; Lingala, V.B.; Singh, G. Declines in mortality from acute myocardial infarction in successive incidence and birth cohorts of patients with rheumatoid arthritis. Circulation 2004, 110, 1774-1779. [CrossRef] [PubMed]

46. Cavagna, L.; Boffini, N.; Cagnotto, G.; Inverardi, F.; Grosso, V.; Caporali, R. Atherosclerosis and rheumatoid arthritis: More than a simple association. Mediat. Inflamm. 2012, 2012, 147354. [CrossRef]

47. Ohta, H.; Wada, H.; Niwa, T.; Kirii, H.; Iwamoto, N.; Fujii, H.; Saito, K.; Sekikawa, K.; Seishima, M. Disruption of tumor necrosis factor-alpha gene diminishes the development of atherosclerosis in ApoE-deficient mice. Atherosclerosis 2005, 180, 11-17. [CrossRef]

48. Devlin, C.M.; Kuriakose, G.; Hirsch, E.; Tabas, I. Genetic alterations of IL-1 receptor antagonist in mice affect plasma cholesterol level and foam cell lesion size. Proc. Natl. Acad. Sci. USA 2002, 99, 6280-6285. [CrossRef] [PubMed]

49. Charo, I.F.; Taub, R. Anti-inflammatory therapeutics for the treatment of atherosclerosis. Nat. Rev. Drug Discov. 2011, 10, 365-376. [CrossRef] [PubMed]

50. Serruys, P.W.; Garcia-Garcia, H.M.; Buszman, P.; Erne, P.; Verheye, S.; Aschermann, M.; Duckers, H.; Bleie, O.; Dudek, D.; Botker, H.E.; et al. Effects of the direct lipoprotein-associated phospholipase A(2) inhibitor darapladib on human coronary atherosclerotic plaque. Circulation 2008, 118, 1172-1182. [CrossRef] [PubMed]

51. Tardif, J.C.; McMurray, J.J.; Klug, E.; Small, R.; Schumi, J.; Choi, J.; Cooper, J.; Scott, R.; Lewis, E.F.; L'Allier, P.L.; et al. Aggressive reduction of inflammation stops events trial, i., effects of succinobucol (AGI-1067) after an acute coronary syndrome: A randomised, double-blind, placebo-controlled trial. Lancet 2008, 371, 1761-1768. [CrossRef]

52. Ridker, P.M.; Rifai, N.; Clearfield, M.; Downs, J.R.; Weis, S.E.; Miles, J.S.; Gotto, A.M., Jr. Air force/Texas coronary atherosclerosis prevention study, i., measurement of C-reactive protein for the targeting of statin therapy in the primary prevention of acute coronary events. N. Engl. J. Med. 2001, 344, 1959-1965. [CrossRef] [PubMed]

53. Ridker, P.M.; Danielson, E.; Fonseca, F.A.; Genest, J.; Gotto, A.M., Jr.; Kastelein, J.J.; Koenig, W.; Libby, P.; Lorenzatti, A.J.; MacFadyen, J.G.; et al. Rosuvastatin to prevent vascular events in men and women with elevated C-reactive protein. N. Engl. J. Med. 2008, 359, 2195-2207. [CrossRef] [PubMed]

54. Zapolska-Downar, D.; Siennicka, A.; Kaczmarczyk, M.; Kolodziej, B.; Naruszewicz, M. Simvastatin modulates TNFalpha-induced adhesion molecules expression in human endothelial cells. Life Sci. 2004, 75, 1287-1302. [CrossRef] [PubMed]

55. Aikawa, M.; Rabkin, E.; Sugiyama, S.; Voglic, S.J.; Fukumoto, Y.; Furukawa, Y.; Shiomi, M.; Schoen, F.J.; Libby, P. An HMG-CoA reductase inhibitor, cerivastatin, suppresses growth of macrophages expressing matrix metalloproteinases and tissue factor in vivo and in vitro. Circulation 2001, 103, 276-283. [CrossRef]

56. Antonopoulos, A.S.; Margaritis, M.; Lee, R.; Channon, K.; Antoniades, C. Statins as anti-inflammatory agents in atherogenesis: Molecular mechanisms and lessons from the recent clinical trials. Curr. Pharm. Des. 2012, 18, 1519-1530. [CrossRef] [PubMed]

57. Pliquett, R.U.; Cornish, K.G.; Peuler, J.D.; Zucker, I.H. Simvastatin normalizes autonomic neural control in experimental heart failure. Circulation 2003, 107, 2493-2498. [CrossRef]

58. Node, K.; Fujita, M.; Kitakaze, M.; Hori, M.; Liao, J.K. Short-term statin therapy improves cardiac function and symptoms in patients with idiopathic dilated cardiomyopathy. Circulation 2003, 108, 839-843. [CrossRef] [PubMed]

59. Iwasaki, A.; Matsumori, A.; Yamada, T.; Shioi, T.; Wang, W.; Ono, K.; Nishio, R.; Okada, M.; Sasayama, S. Pimobendan inhibits the production of proinflammatory cytokines and gene expression of inducible nitric oxide synthase in a murine model of viral myocarditis. J. Am. Coll. Cardiol. 1999, 33, 1400-1407. [CrossRef] 
60. Matsumori, A.; Nunokawa, Y.; Sasayama, S. Pimobendan inhibits the activation of transcription factor NF-kappaB: A mechanism which explains its inhibition of cytokine production and inducible nitric oxide synthase. Life Sci. 2000, 67, 2513-2519. [CrossRef]

61. Effects of Pimobendan on Chronic Heart Failure Study. Effects of pimobendan on adverse cardiac events and physical activities in patients with mild to moderate chronic heart failure: The effects of pimobendan on chronic heart failure study (EPOCH study). Circ. J. 2002, 66, 149-157.

62. Matsumori, A.; Ono, K.; Nishio, R.; Nose, Y.; Sasayama, S. Amiodarone inhibits production of tumor necrosis factor-alpha by human mononuclear cells: A possible mechanism for its effect in heart failure. Circulation 1997, 96, 1386-1389. [CrossRef]

63. Ito, H.; Ono, K.; Nishio, R.; Sasayama, S.; Matsumori, A. Amiodarone inhibits interleukin 6 production and attenuates myocardial injury induced by viral myocarditis in mice. Cytokine 2002, 17, 197-202. [CrossRef] [PubMed]

64. Chenevard, R.; Hurlimann, D.; Bechir, M.; Enseleit, F.; Spieker, L.; Hermann, M.; Riesen, W.; Gay, S.; Gay, R.E.; Neidhart, M.; et al. Selective COX-2 inhibition improves endothelial function in coronary artery disease. Circulation 2003, 107, 405-409. [CrossRef]

65. Widlansky, M.E.; Price, D.T.; Gokce, N.; Eberhardt, R.T.; Duffy, S.J.; Holbrook, M.; Maxwell, C.; Palmisano, J.; Keaney, J.F., Jr.; Morrow, J.D.; et al. Short- and long-term COX-2 inhibition reverses endothelial dysfunction in patients with hypertension. Hypertension 2003, 42, 310-315. [CrossRef]

66. Fliser, D.; Buchholz, K.; Haller, H. Antiinflammatory effects of angiotensin II subtype 1 receptor blockade in hypertensive patients with microinflammation. Circulation 2004, 110, 1103-1107. [CrossRef] [PubMed]

67. Ridker, P.M.; Everett, B.M.; Thuren, T.; MacFadyen, J.G.; Chang, W.H.; Ballantyne, C.; Fonseca, F.; Nicolau, J.; Koenig, W.; Anker, S.D.; et al. Antiinflammatory therapy with canakinumab for atherosclerotic disease. N. Engl. J. Med. 2017, 377, 1119-1131. [CrossRef]

68. Loppnow, H.; Libby, P. Proliferating or interleukin 1-activated human vascular smooth muscle cells secrete copious interleukin 6. J. Clin. Investig. 1990, 85, 731-738. [CrossRef] [PubMed]

69. Ridker, P.M.; Libby, P.; MacFadyen, J.G.; Thuren, T.; Ballantyne, C.; Fonseca, F.; Koenig, W.; Shimokawa, H.; Everett, B.M.; Glynn, R.J. Modulation of the interleukin-6 signalling pathway and incidence rates of atherosclerotic events and all-cause mortality: Analyses from the canakinumab anti-inflammatory thrombosis outcomes study (CANTOS). Eur. Heart J. 2018, 39, 3499-3507. [CrossRef] [PubMed]

70. Kleveland, O.; Kunszt, G.; Bratlie, M.; Ueland, T.; Broch, K.; Holte, E.; Michelsen, A.E.; Bendz, B.; Amundsen, B.H.; Espevik, T.; et al. Effect of a single dose of the interleukin-6 receptor antagonist tocilizumab on inflammation and troponin $\mathrm{T}$ release in patients with non-ST-elevation myocardial infarction: A double-blind, randomized, placebo-controlled phase 2 trial. Eur. Heart J. 2016, 37, 2406-2413. [CrossRef]

71. Ridker, P.M.; Everett, B.M.; Pradhan, A.; MacFadyen, J.G.; Solomon, D.H.; Zaharris, E.; Mam, V.; Hasan, A.; Rosenberg, Y.; Iturriaga, E.; et al. Low-dose methotrexate for the prevention of atherosclerotic events. N. Engl. J. Med. 2019, 380, 752-762. [CrossRef] [PubMed]

72. Chung, E.S.; Packer, M.; Lo, K.H.; Fasanmade, A.A.; Willerson, J.T. Randomized, double-blind, placebo-controlled, pilot trial of infliximab, a chimeric monoclonal antibody to tumor necrosis factor-alpha, in patients with moderate-to-severe heart failure: Results of the anti-TNF therapy against congestive heart failure (ATTACH) trial. Circulation 2003, 107, 3133-3140. [PubMed]

73. Gilmore, T.D. Introduction to NF-kappaB: Players, pathways, perspectives. Oncogene 2006, 25, 6680-6684. [CrossRef] [PubMed]

74. Brasier, A.R. The NF-kappaB regulatory network. Cardiovasc. Toxicol. 2006, 6, 111-130. [CrossRef] [PubMed]

75. Perkins, N.D. Integrating cell-signalling pathways with NF-kappaB and IKK function. Nat. Rev. 2007, 8, 49-62. [CrossRef] [PubMed]

76. Gilmore, T.D. The Rel/NF-kappaB signal transduction pathway: Introduction. Oncogene 1999, 18, $6842-6844$. [CrossRef]

77. Tian, B.; Brasier, A.R. Identification of a nuclear factor kappa B-dependent gene network. Recent Prog. Horm. Res. 2003, 58, 95-130. [CrossRef] [PubMed]

78. Sun, S.C. The noncanonical NF-kappaB pathway. Immunol. Rev. 2012, 246, 125-140. [CrossRef] [PubMed]

79. Epelman, S.; Liu, P.P.; Mann, D.L. Role of innate and adaptive immune mechanisms in cardiac injury and repair. Nat. Rev. Immunol. 2015, 15, 117-129. [CrossRef] 
80. Baldwin, A.S., Jr. Series introduction: The transcription factor NF-kappaB and human disease. J. Clin. Investig. 2001, 107, 3-6. [CrossRef]

81. Kumar, A.; Takada, Y.; Boriek, A.M.; Aggarwal, B.B. Nuclear factor-kappaB: Its role in health and disease. J. Mol. Med. 2004, 82, 434-448. [CrossRef] [PubMed]

82. Yamamoto, Y.; Gaynor, R.B. Role of the NF-kappaB pathway in the pathogenesis of human disease states. Curr. Mol. Med. 2001, 1, 287-296. [CrossRef]

83. Hayden, M.S.; Ghosh, S. Shared principles in NF-kappaB signaling. Cell 2008, 132, 344-362. [CrossRef] [PubMed]

84. Sorriento, D.; Santulli, G.; Franco, A.; Cipolletta, E.; Napolitano, L.; Gambardella, J.; Gomez-Monterrey, I.; Campiglia, P.; Trimarco, B.; Iaccarino, G.; et al. Integrating GRK2 and NFkappaB in the Pathophysiology of Cardiac Hypertrophy. J. Cardiovasc. Transl. Res. 2015, 8, 493-502. [CrossRef]

85. Sorriento, D.; Santulli, G.; Fusco, A.; Anastasio, A.; Trimarco, B.; Iaccarino, G. Intracardiac injection of AdGRK5-NT reduces left ventricular hypertrophy by inhibiting NF-kappaB-dependent hypertrophic gene expression. Hypertension 2010, 56, 696-704. [CrossRef]

86. Ritchie, M.E. Nuclear factor-kappaB is selectively and markedly activated in humans with unstable angina pectoris. Circulation 1998, 98, 1707-1713. [CrossRef] [PubMed]

87. Chandrasekar, B.; Freeman, G.L. Induction of nuclear factor kappaB and activation protein 1 in postischemic myocardium. FEBS Lett. 1997, 401, 30-34. [CrossRef]

88. Li, C.; Kao, R.L.; Ha, T.; Kelley, J.; Browder, I.W.; Williams, D.L. Early activation of IKKbeta during in vivo myocardial ischemia. Am. J. Physiol. Heart Circ. Physiol. 2001, 280, H1264-H1271. [CrossRef]

89. Li, C.; Browder, W.; Kao, R.L. Early activation of transcription factor NF-kappaB during ischemia in perfused rat heart. Am. J. Physiol. 1999, 276, H543-H552.

90. Valen, G.; Hansson, G.K.; Dumitrescu, A.; Vaage, J. Unstable angina activates myocardial heat shock protein 72, endothelial nitric oxide synthase, and transcription factors NFkappaB and AP-1. Cardiovasc. Res. 2000, 47, 49-56. [CrossRef]

91. Valen, G. Signal transduction through nuclear factor kappa B in ischemia-reperfusion and heart failure. Basic Res. Cardiol. 2004, 99, 1-7. [CrossRef]

92. Siednienko, J.; Jankowska, E.A.; Banasiak, W.; Gorczyca, W.A.; Ponikowski, P. Nuclear factor-kappaB activity in peripheral blood mononuclear cells in cachectic and non-cachectic patients with chronic heart failure. Int. J. Cardiol. 2007, 122, 111-116. [CrossRef]

93. Frantz, S.; Stoerk, S.; Ok, S.; Wagner, H.; Angermann, C.E.; Ertl, G.; Bauersachs, J. Effect of chronic heart failure on nuclear factor kappa B in peripheral leukocytes. Am. J. Cardiol. 2004, 94, 671-673. [CrossRef]

94. Shaw, J.; Zhang, T.; Rzeszutek, M.; Yurkova, N.; Baetz, D.; Davie, J.R.; Kirshenbaum, L.A. Transcriptional silencing of the death gene BNIP3 by cooperative action of NF-kappaB and histone deacetylase 1 in ventricular myocytes. Circ. Res. 2006, 99, 1347-1354. [CrossRef] [PubMed]

95. Gordon, J.W.; Shaw, J.A.; Kirshenbaum, L.A. Multiple facets of NF-kappaB in the heart: To be or not to NF-kappaB. Circ. Res. 2011, 108, 1122-1132. [CrossRef] [PubMed]

96. Maier, H.J.; Schips, T.G.; Wietelmann, A.; Kruger, M.; Brunner, C.; Sauter, M.; Klingel, K.; Bottger, T.; Braun, T.; Wirth, T. Cardiomyocyte-specific IkappaB kinase (IKK)/NF-kappaB activation induces reversible inflammatory cardiomyopathy and heart failure. Proc. Natl. Acad. Sci. USA 2012, 109, 11794-11799. [CrossRef]

97. Hamid, T.; Guo, S.Z.; Kingery, J.R.; Xiang, X.; Dawn, B.; Prabhu, S.D. Cardiomyocyte NF-kappaB p65 promotes adverse remodelling, apoptosis, and endoplasmic reticulum stress in heart failure. Cardiovasc. Res. 2011, 89, 129-138. [CrossRef]

98. Liu, Q.; Chen, Y.; Auger-Messier, M.; Molkentin, J.D. Interaction between NFkappaB and NFAT coordinates cardiac hypertrophy and pathological remodeling. Circ. Res. 2012, 110, 1077-1086. [CrossRef] [PubMed]

99. Gupta, S.; Young, D.; Maitra, R.K.; Gupta, A.; Popovic, Z.B.; Yong, S.L.; Mahajan, A.; Wang, Q.; Sen, S. Prevention of cardiac hypertrophy and heart failure by silencing of NF-kappaB. J. Mol. Biol. 2008, 375, 637-649. [CrossRef]

100. Donnarumma, E.; Ali, M.J.; Rushing, A.M.; Scarborough, A.L.; Bradley, J.M.; Organ, C.L.; Islam, K.N.; Polhemus, D.J.; Evangelista, S.; Cirino, G.; et al. Zofenopril protects against myocardial ischemia-reperfusion injury by increasing nitric oxide and hydrogen sulfide bioavailability. J. Am. Heart. Assoc. 2016, 5, e003531. [CrossRef] [PubMed] 
101. Fratta Pasini, A.; Garbin, U.; Nava, M.C.; Stranieri, C.; Davoli, A.; Sawamura, T.; Lo Cascio, V.; Cominacini, L. Nebivolol decreases oxidative stress in essential hypertensive patients and increases nitric oxide by reducing its oxidative inactivation. J. Hypertens. 2005, 23, 589-596. [CrossRef] [PubMed]

102. Mahajan, A.S.; Babbar, R.; Kansal, N.; Agarwal, S.K.; Ray, P.C. Antihypertensive and antioxidant action of amlodipine and vitamin $C$ in patients of essential hypertension. J. Clin. Biochem. Nutr. 2007, 40, 141-147. [CrossRef]

103. Yao, E.H.; Fukuda, N.; Matsumoto, T.; Katakawa, M.; Yamamoto, C.; Han, Y.; Ueno, T.; Kobayashi, N.; Matsumoto, K. Effects of the antioxidative beta-blocker celiprolol on endothelial progenitor cells in hypertensive rats. Am. J. Hypertens. 2008, 21, 1062-1068. [CrossRef]

104. Gupta, S.C.; Sundaram, C.; Reuter, S.; Aggarwal, B.B. Inhibiting NF-kappaB activation by small molecules as a therapeutic strategy. Biochim. Biophys. Acta 2010, 1799, 775-787. [CrossRef]

105. Vafadari, R.; Kraaijeveld, R.; Weimar, W.; Baan, C.C. Tacrolimus inhibits NF-kappaB activation in peripheral human T cells. PLoS ONE 2013, 8, e60784. [CrossRef]

106. Mishra, K.P.; Chanda, S.; Karan, D.; Ganju, L.; Sawhney, R.C. Effect of Seabuckthorn (Hippophae rhamnoides) flavone on immune system: An in-vitro approach. Phytother. Res. 2008, 22, 1490-1495. [CrossRef]

107. Kasinski, A.L.; Du, Y.; Thomas, S.L.; Zhao, J.; Sun, S.Y.; Khuri, F.R.; Wang, C.Y.; Shoji, M.; Sun, A.; Snyder, J.P.; et al. Inhibition of IkappaB kinase-nuclear factor-kappaB signaling pathway by 3,5-bis(2-flurobenzylidene)piperidin-4-one (EF24), a novel monoketone analog of curcumin. Mol. Pharmacol. 2008, 74, 654-661. [CrossRef]

108. Pujols, L.; Fernandez-Bertolin, L.; Fuentes-Prado, M.; Alobid, I.; Roca-Ferrer, J.; Agell, N.; Mullol, J.; Picado, C. Proteasome inhibition reduces proliferation, collagen expression, and inflammatory cytokine production in nasal mucosa and polyp fibroblasts. J. Pharmacol. Exp. Ther. 2012, 343, 184-197. [CrossRef] [PubMed]

109. Momose, I.; Iijima, M.; Kawada, M.; Ikeda, D. A new proteasome inhibitor, TP-110, induces apoptosis in human prostate cancer PC-3 cells. Biosci. Biotechnol. Biochem. 2007, 71, 1036-1043. [CrossRef]

110. Nam, K.N.; Son, M.S.; Park, J.H.; Lee, E.H. Shikonins attenuate microglial inflammatory responses by inhibition of ERK, Akt, and NF-kappaB: Neuroprotective implications. Neuropharmacology 2008, 55, 819-825. [CrossRef] [PubMed]

111. Nakagawa, R.; Naka, T.; Tsutsui, H.; Fujimoto, M.; Kimura, A.; Abe, T.; Seki, E.; Sato, S.; Takeuchi, O.; Takeda, K.; et al. SOCS-1 participates in negative regulation of LPS responses. Immunity 2002, 17, 677-687. [CrossRef]

112. Iwamoto, S.; Kumamoto, T.; Azuma, E.; Hirayama, M.; Ito, M.; Amano, K.; Ido, M.; Komada, Y. The effect of azithromycin on the maturation and function of murine bone marrow-derived dendritic cells. Clin. Exp. Immunol. 2011, 166, 385-392. [CrossRef] [PubMed]

113. Pradeep, C.R.; Kuttan, G. Piperine is a potent inhibitor of nuclear factor-kappaB (NF-kappaB), c-Fos, CREB, ATF-2 and proinflammatory cytokine gene expression in B16F-10 melanoma cells. Int. Immunopharmacol. 2004, 4, 1795-1803. [CrossRef] [PubMed]

114. Belmonte, S.L.; Blaxall, B.C. G protein coupled receptor kinases as therapeutic targets in cardiovascular disease. Circ. Res. 2011, 109, 309-319. [CrossRef]

115. Sorriento, D.; Ciccarelli, M.; Cipolletta, E.; Trimarco, B.; Iaccarino, G. "Freeze, don't move": How to arrest a suspect in heart failure-A review on available GRK2 inhibitors. Front. Cardiovasc. Med. 2016, 3, 48. [CrossRef] [PubMed]

116. Gambardella, J.; Trimarco, B.; Iaccarino, G.; Sorriento, D. Cardiac nonmyocyte cell functions and crosstalks in response to cardiotoxic drugs. Oxid. Med. Cell. Longev. 2017, 2017, 1089359. [CrossRef]

117. Sorriento, D.; Ciccarelli, M.; Santulli, G.; Illario, M.; Trimarco, B.; Iaccarino, G. Trafficking GRK2: Cellular and Metabolic consequences of GRK2 subcellular localization. Transl. Med. UniSa 2014, 10, 3-7.

118. Sorriento, D.; Pascale, A.V.; Finelli, R.; Carillo, A.L.; Annunziata, R.; Trimarco, B.; Iaccarino, G. Targeting mitochondria as therapeutic strategy for metabolic disorders. Sci. World J. 2014, 2014, 604685. [CrossRef]

119. Mak, J.C.; Hisada, T.; Salmon, M.; Barnes, P.J.; Chung, K.F. Glucocorticoids reverse IL-1beta-induced impairment of beta-adrenoceptor-mediated relaxation and up-regulation of G-protein-coupled receptor kinases. Br. J. Pharmacol. 2002, 135, 987-996. [CrossRef]

120. Lombardi, M.S.; Kavelaars, A.; Cobelens, P.M.; Schmidt, R.E.; Schedlowski, M.; Heijnen, C.J. Adjuvant arthritis induces down-regulation of $\mathrm{G}$ protein-coupled receptor kinases in the immune system. J. Immunol. 2001, 166, 1635-1640. [CrossRef] 
121. Sorriento, D.; Fusco, A.; Ciccarelli, M.; Rungi, A.; Anastasio, A.; Carillo, A.; Dorn, G.W., 2nd; Trimarco, B.; Iaccarino, G. Mitochondrial $\mathrm{G}$ protein coupled receptor kinase 2 regulates proinflammatory responses in macrophages. FEBS Lett. 2013, 587, 3487-3494. [CrossRef] [PubMed]

122. Vroon, A.; Kavelaars, A.; Limmroth, V.; Lombardi, M.S.; Goebel, M.U.; Van Dam, A.M.; Caron, M.G.; Schedlowski, M.; Heijnen, C.J. G protein-coupled receptor kinase 2 in multiple sclerosis and experimental autoimmune encephalomyelitis. J. Immunol. 2005, 174, 4400-4406. [CrossRef] [PubMed]

123. Tarrant, T.K.; Rampersad, R.R.; Esserman, D.; Rothlein, L.R.; Liu, P.; Premont, R.T.; Lefkowitz, R.J.; Lee, D.M.; Patel, D.D. Granulocyte chemotaxis and disease expression are differentially regulated by GRK subtype in an acute inflammatory arthritis model (K/BxN). Clin. Immunol. 2008, 129, 115-122. [CrossRef] [PubMed]

124. Lombardi, M.S.; Kavelaars, A.; Schedlowski, M.; Bijlsma, J.W.; Okihara, K.L.; Van de Pol, M.; Ochsmann, S.; Pawlak, C.; Schmidt, R.E.; Heijnen, C.J. Decreased expression and activity of G-protein-coupled receptor kinases in peripheral blood mononuclear cells of patients with rheumatoid arthritis. FASEB J. 1999, 13, 715-725. [CrossRef] [PubMed]

125. Fu, X.; Koller, S.; Abd Alla, J.; Quitterer, U. Inhibition of G-protein-coupled receptor kinase 2 (GRK2) triggers the growth-promoting mitogen-activated protein kinase (MAPK) pathway. J. Biol. Chem. 2013, 288, 7738-7755. [CrossRef] [PubMed]

126. Parameswaran, N.; Pao, C.S.; Leonhard, K.S.; Kang, D.S.; Kratz, M.; Ley, S.C.; Benovic, J.L. Arrestin-2 and $G$ protein-coupled receptor kinase 5 interact with NFkappaB1 p105 and negatively regulate lipopolysaccharide-stimulated ERK1/2 activation in macrophages. J. Biol. Chem. 2006, 281, 34159-34170. [CrossRef] [PubMed]

127. Steury, M.D.; McCabe, L.R.; Parameswaran, N. G protein-coupled receptor kinases in the inflammatory response and signaling. Adv. Immunol. 2017, 136, 227-277. [PubMed]

128. Patial, S.; Luo, J.; Porter, K.J.; Benovic, J.L.; Parameswaran, N. G-protein-coupled-receptor kinases mediate TNFalpha-induced NFkappaB signalling via direct interaction with and phosphorylation of IkappaBalpha. Biochem. J. 2009, 425, 169-178. [CrossRef]

129. Patial, S.; Saini, Y.; Parvataneni, S.; Appledorn, D.M.; Dorn, G.W., 2nd; Lapres, J.J.; Amalfitano, A.; Senagore, P.; Parameswaran, N. Myeloid-specific GPCR kinase-2 negatively regulates NF-kappaB1p105-ERK pathway and limits endotoxemic shock in mice. J. Cell. Physiol. 2011, 226, 627-637. [CrossRef]

130. Xu, F.; Sun, S.; Wang, X.; Ni, E.; Zhao, L.; Zhu, W. GRK2 mediates arginine vasopressin-induced interleukin-6 production via nuclear factor-kappab signaling neonatal rat cardiac fibroblast. Mol. Pharmacol. 2017, 92, 278-284. [CrossRef] [PubMed]

131. Sorriento, D.; Ciccarelli, M.; Santulli, G.; Campanile, A.; Altobelli, G.G.; Cimini, V.; Galasso, G.; Astone, D.; Piscione, F.; Pastore, L.; et al. The G-protein-coupled receptor kinase 5 inhibits NFkappaB transcriptional activity by inducing nuclear accumulation of IkappaB alpha. Proc. Natl. Acad. Sci. USA 2008, 105, 17818-17823. [CrossRef]

132. Ohba, Y.; Nakaya, M.; Watari, K.; Nagasaka, A.; Kurose, H. GRK6 phosphorylates IkappaBalpha at Ser(32)/Ser(36) and enhances TNF-alpha-induced inflammation. Biochem. Biophys. Res. Commun. 2015, 461, 307-313. [CrossRef] [PubMed]

133. Sorriento, D.; Santulli, G.; Ciccarelli, M.; Maione, A.S.; Illario, M.; Trimarco, B.; Iaccarino, G. The amino-terminal domain of GRK5 inhibits cardiac hypertrophy through the regulation of calcium-calmodulin dependent transcription factors. Int. J. Mol. Sci. 2018, 19, 861. [CrossRef] [PubMed]

134. Sorriento, D.; Campanile, A.; Santulli, G.; Leggiero, E.; Pastore, L.; Trimarco, B.; Iaccarino, G. A new synthetic protein, TAT-RH, inhibits tumor growth through the regulation of NFkappaB activity. Mol. Cancer 2009, 8, 1. [CrossRef] [PubMed]

135. Gambardella, J.; Ciccarelli, M.; Del Giudice, C.; Fiordelisi, A.; De Rosa, M.; Sala, M.; Pacelli, R.; Campiglia, P.; Trimarco, B.; Iaccarino, G.; et al. A novel small peptide inhibitor of NFkappaB, RH10, blocks oxidative stress-dependent phenotypes in cancer. Oxid. Med. Cell. Longev. 2018, 2018, 5801807. [CrossRef] [PubMed] 
136. Parameswaran, R.; Lunning, M.; Mantha, S.; Devlin, S.; Hamilton, A.; Schwartz, G.; Soff, G. Romiplostim for management of chemotherapy-induced thrombocytopenia. Support. Care Cancer 2014, 22, 1217-1222. [CrossRef] [PubMed]

137. Cipolletta, E.; Campanile, A.; Santulli, G.; Sanzari, E.; Leosco, D.; Campiglia, P.; Trimarco, B.; Iaccarino, G. The $G$ protein coupled receptor kinase 2 plays an essential role in beta-adrenergic receptor-induced insulin resistance. Cardiovasc. Res. 2009, 84, 407-415. [CrossRef] [PubMed] 